Article

\title{
Effects of Steel Slag and Biochar Incorporation on Active Soil Organic Carbon Pools in a Subtropical Paddy Field
}

\author{
Weiqi Wang 1,2,*, Derrick Yuk Fo Lai ${ }^{3, *(\mathbb{D})}$, Abbas Ali Abid ${ }^{4}$, Suvadip Neogi ${ }^{3}$ (D) , Xuping Xu 5 \\ and Chun Wang ${ }^{1,2}$ \\ 1 Institute of Geography, Fujian Normal University, Fuzhou 350007, China; wangchun821314@163.com \\ 2 Key Laboratory of Humid Subtropical Eco-geographical Process, Ministry of Education, Fujian Normal \\ University, Fuzhou 350007, China \\ 3 Department of Geography and Resource Management, The Chinese University of Hong Kong, \\ Hong Kong, China; suvadip_ng@yahoo.co.in \\ 4 Zhejiang Provincial Key Laboratory of Agricultural Resources and Environment, Key Laboratory of \\ Environment Remediation and Ecological Health, Ministry of Education, Zhejiang University, \\ Hangzhou 310058, China; abbas@zju.edu.cn \\ 5 College of Life Science, Fujian Normal University, Fuzhou 350007, China; xuping@fjnu.edu.cn \\ * Correspondence: wangweiqi@fjnu.edu.cn (W.W.); dyflai@cuhk.edu.hk (D.Y.F.L.); \\ Tel.: +86-591-8346-5214 (W.W.); +852-3943-6528 (D.Y.F.L.)
}

Received: 29 May 2018; Accepted: 31 July 2018; Published: 2 August 2018

\begin{abstract}
Industrial wastes and agricultural byproducts are increasingly used in crop production as fertilizers, but their impacts on soil carbon (C) sequestration remain poorly understood. The aim of this study was to examine the effects of applying steel slag (SS), biochar (B), and a combination of these two materials (SS + B) on total soil organic C (SOC), active SOC fractions, and C pool management index (CPMI) in a subtropical paddy field in China. The treatments were applied at a rate of $8 \mathrm{tha}^{-1}$ to rice at the two (early and late) crop seasons in 2015. The SOC concentrations in the top $30 \mathrm{~cm}$ soils in the SS + B treatments were $28.7 \%$ and $42.2 \%$ higher in the early and late crops, respectively, as compared to the controls $(p<0.05)$. SOC was positively correlated with soil $\mathrm{C}: \mathrm{N}$ ratio across the two crop seasons $(r=0.92-0.97, p<0.01)$. As compared to the control, $\mathrm{SS}+\mathrm{B}$ treatment had significantly higher carbon pool index (CPI) in both early $(22.4 \%)$ and late $(40.1 \%)$ crops. In the early crop, the $\mathrm{C}$ pool activity index (CPAI) was significantly lower in B and SS + B treatments by over $50 \%$ than in the control, while the soil C pool management index (CPMI) in the SS, B, and SS + B treatments was lower than that in the control by $36.7 \%, 41.6 \%$, and $45.4 \%$, respectively. In contrast, in the late crop, no significant differences in CPAI and CPMI were observed among the treatments. Our findings suggest that the addition of steel slag and biochar in subtropical paddy fields could decrease active SOC pools and enhance soil C sequestration only in the early crop, but not the late crop.
\end{abstract}

Keywords: rice paddy; active carbon; biochar; steel slag; soil organic carbon

\section{Introduction}

Global climate change is regarded as one of the major environmental problems in the 21st century. Enhancing soil carbon (C) sequestration and reducing greenhouse gas (GHG) emissions in agriculture are some of the key approaches to minimize the impacts of agriculture on climate change [1]. Paddy fields in China account for $23 \%$ of the country's cultivated lands and comprise approximately $20 \%$ of the world's total rice production areas [2], thus, investigating the GHG dynamics in Chinese 
paddy fields has significant implications to atmospheric chemistry and climate change at both national and global levels [3].

Rice (Oryza sativa L.) is a major cereal crop that currently supports more than $50 \%$ of the global population [4]. To satisfy the food demand by the world's ever-increasing population, rice production may have to increase by $40 \%$ by 2030 [5]. Given that paddy fields have a much higher $C$ sequestration potential than dry croplands [6], rice cultivation can play a potentially important role in mitigating the rapid increase in atmospheric $\mathrm{CO}_{2}$ [7]. Currently, the total $\mathrm{C}$ stock in the paddy soils of China is $1.3 \mathrm{Pg}$ [6], which is considerably lower than that of 21.0 and $41.0 \mathrm{Pg}$ reported in the soils of Chinese forests [8] and grasslands [9], respectively. With the relatively small amount of soil organic carbon (SOC) currently present, paddy soils may offer a great potential to sequester $\mathrm{C}$, provided that suitable management practices are applied $[10,11]$.

Numerous strategies have been explored by researchers to enhance $C$ sequestration in paddy soils. For example, the application of exotic materials such as biochar [12] and steel slag [13] has been proposed as a viable option to improve rice yields and mitigate GHG emissions concurrently $[1,14]$. Steel industries and paddy farming usually generate a huge amount of waste materials in the forms of sludge slag and agricultural by-products, respectively. Transforming these solid wastes into usable materials is highly desirable for the conservation of natural resources and the development of sustainable agricultural systems. Steel slag is rich in ferric iron and other nutrients. When applied in paddy fields, the slag can raise soil $\mathrm{pH}$, reduce methane emission, mediate soil quality and increase rice yield. Biochar produced by pyrolysis of biomass [15] has been shown to have potential in sequestering atmospheric $\mathrm{CO}_{2}$ over millenia [16] and improving soil quality [15,17]. While steel slag and biochar have been widely used as soil amendments worldwide [18-20], their independent and interactive effects on the soil $C$ pool, in particular the active $C$ fractions, remain poorly understood.

Soil $C$ typically exists in various forms with different degrees of lability. The fraction of active $C$ in soil is strongly influenced by plants and microbes and is highly susceptible to oxidation and decomposition processes [21,22]. Distinguishing active $C$ fraction from total SOC pool is crucial for assessing the effects of agricultural management practices on soil $\mathrm{C}$ dynamics in rice cultivation systems [23-26]. Owing to the large size of the existing $C$ stock in soils, any small changes in SOC from one year to the next are difficult to be quantified by any existing analytical equipment and methodology. Hence, it is very challenging to accurately determine the management impacts on soil C dynamics using total organic carbon (TOC) as an indicator based on short-term studies [23]. In contrast, quantifying labile SOC factions, such as microbial biomass $\mathrm{C}(\mathrm{MBC})$, dissolved organic $C$ (DOC), and other labile organic C (LOC) compounds, can help to elucidate the rapid response of soil $C$ to the implementation of various management practices. Soil $C$ and nitrogen contents can be influenced by environmental and anthropogenic factors [27]. Also, cropping practices, such as fertilization [28], tillage [29], planting configuration [30], crop rotation, and systems integration [31], can play a key role in governing the $\mathrm{C}$ and $\mathrm{N}$ dynamics and hence GHG emissions in agricultural soils. Effective management of active $C$ pool in soils is therefore important to mitigate GHG emissions to the atmosphere [27,32-37]. Previous studies have applied the C pool management index (CPMI) to assess the response of SOC content to changes in environmental conditions and management practices in field crops such as maize (Zea mays L.), wheat and millet (Pennisetum glaucum L.) $[26,33,34]$. The CPMI methodology could potentially be used to quantify SOC changes in flooded paddy fields.

China has the second largest rice cultivation area in the world [38], with $90 \%$ of the Chinese paddy fields being located in the subtropics, mostly in Fujian, Jiangxi and Hunan Provinces. It is of national and global interests to formulate effective strategies that can simultaneously increase the cost-effectiveness of paddy farming, and enhance both crop yields and soil C storage. Furthermore, industrial and agricultural wastes are far less commonly applied in subtropical paddy fields than their temperate counterparts $[14,18,39]$, and their impacts on active soil $\mathrm{C}$ pools in subtropical environments are largely unknown. In particular, it is not clear whether the combined application of these amendments would bring about synergistic or antagonistic effects on soil $\mathrm{C}$ as compared to 
applying these materials separately in a field setting. The objectives of this study were to: (1) investigate the effects of combined steel slag and biochar incorporation on the total and active SOC concentrations in subtropical paddy fields; (2) examine their impact on the relationships between different active SOC fractions and other soil properties; and (3) evaluate whether $C$ pool management index can be used to determine the sensitivity of SOC to steel slag and biochar application in paddy crops.

\section{Materials and Methods}

\subsection{Study Site and Experimental Design}

A field experiment was conducted in the Fujian Academy of Agricultural Sciences, Fujian, Southeastern China ( $26.1^{\circ} \mathrm{N}, 119.3^{\circ} \mathrm{E}$ ) in successive early (16 April to $16 \mathrm{July}$ ) and late paddy seasons (25 July to 6 November) in 2015 (Figure 1) in order to understand the the impacts of steel slag and biochar amendments on soil carbon dynamics comprehensively over one annual cycle. The soil was mainly as silt, and slightly acid with low $C$ content $[1,14]$. The steel slag was collected from Jinxing Iron and Steel Co. Ltd., Fuzhou, Fujian, China. The rice straw used for biochar production was collected from Qinfeng Straw Technology Co. Ltd., Nanjing, Jiangsu, China. The biochar was subsequently prepared by pyrolysis at a temperature of $600{ }^{\circ} \mathrm{C}$ for $90 \mathrm{~min}$. Chemical compositions of the two soil amendments were measured (Table S1).

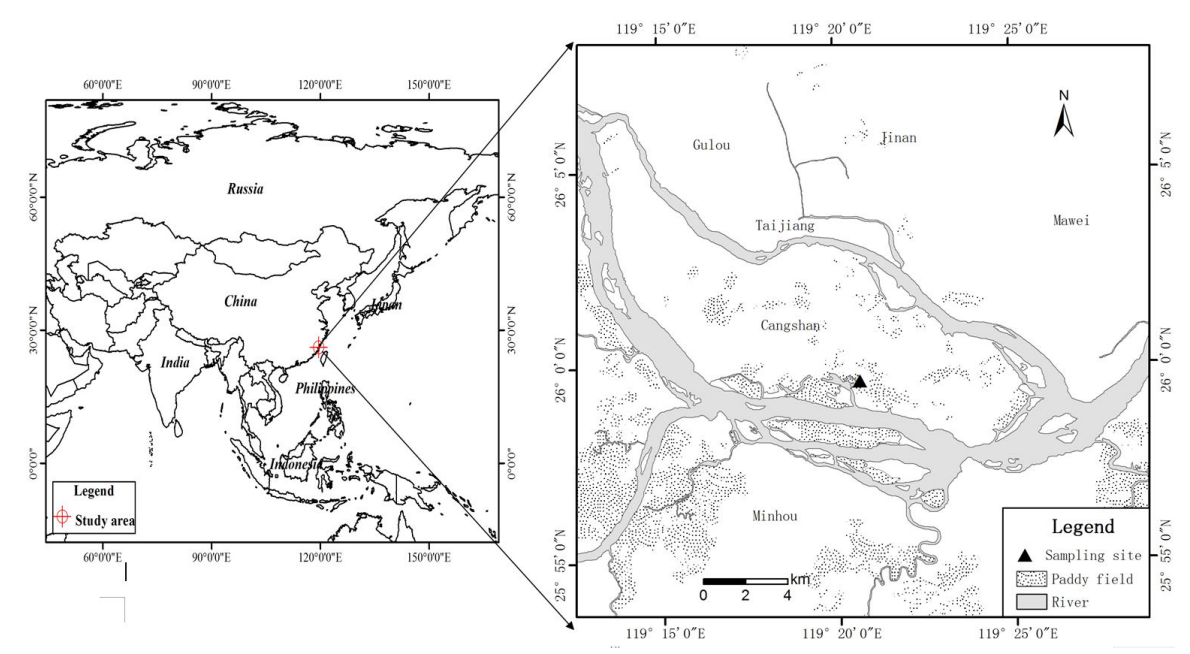

Figure 1. The location of the study area and sampling site $(\mathbf{\Lambda})$ in southeast China.

The experimental plots were laid out in a randomized block design, with triplicate plots $\left(10 \mathrm{~m}^{2}\right)$ for each of the four treatments (including a control). PVC boards $(0.5 \mathrm{~cm}$ thick, $30 \mathrm{~cm}$ high) were installed along the margins of each plot to prevent the exchange of water and nutrients across different treatment plots. In each plot, rice seedlings (early rice cultivar: Hesheng 10; late rice cultivar: Qinxiangyou 212) of about one-month-old were transplanted from seed beds/nurseries to a soil depth of $5 \mathrm{~cm}$ with a spacing of $14 \times 28 \mathrm{~cm}$ using a rice transplanter. The plots were then plowed at a depth of $15 \mathrm{~cm}$ with a moldboard plow and leveled immediately two days before rice transplanting. The experimental treatments were as follows: (1) Control: Mineral fertilizer + urea; (2) Steel slag: Mineral fertilizer + urea + Steel slag; (3) Biochar: Mineral fertilizer + urea + Biochar; (4) Steel slag + biochar: Mineral fertilizer + urea + Steel slag + Biochar. In these treatments, mineral fertilizers were applied as complete ( $\mathrm{N}-\mathrm{P}_{2} \mathrm{O}_{5}-\mathrm{K}_{2} \mathrm{O}$ at 16-16-16\%; Keda Fertilizer Co., Ltd., Jingzhou, Hubei, China) and urea $(46 \% \mathrm{~N})$ fertilizers, with the rates of $\mathrm{N}, \mathrm{P}_{2} \mathrm{O}_{5}, \mathrm{~K}_{2} \mathrm{O}$ addition being $95,70,70 \mathrm{~kg}^{-1}$, respectively. Steel slag and biochar were applied as a single basal dose of $8 \mathrm{t} \mathrm{ha}^{-1}$, which was an intermediate dosage rate used in previous experiments [39,40]. We adopted other management practices that were typical in the subtropical paddy fields of China [41,42], with the details being described in 
the Supplementary information $[1,14]$. Figure S1 shows the air temperature and rainfall during the study period.

\subsection{Determination of Soil Properties and Calculation of CPMI}

Triplicate soil samples were collected from the field for each of the four treatments after rice harvest in both the early and late paddy fields, resulting in a total of 48 soil samples $(0-15$ and $15-30 \mathrm{~cm}$ depths). Microbial biomass carbon (MBC) and dissolved organic carbon (DOC) were measured using fresh soils, while total organic carbon (TOC) and labile organic carbon (LOC) were determined using air-dried and finely grounded soils. Soil TOC concentration was determined using an elemental analyzer (Elementar Vario MAX, Elementar Scientific Instruments, Hanau, Germany). Soil DOC concentration was determined using a total organic carbon analyzer (TOC-V, Shimadzu Scientific Instruments, Kyoto, Japan), after extracting the soils with deionized water (1:5 w/v). Soil MBC was determined by the fumigation-extraction method [43], while soil LOC was determined by the $333 \mathrm{mM}$ $\mathrm{KMnO}_{4}$ digestion method [26,41], in which soil slurry (soil to distilled water ratio of 1:5 $(w / v)$ was shaken at $300 \mathrm{rpm}$ for $30 \mathrm{~min}$ at $25^{\circ} \mathrm{C}$, centrifuged at 10,000 rpm for $20 \mathrm{~min}$, and then filtered through a decarbonized $0.45 \mu \mathrm{m}$ filter. The $\mathrm{C}$ concentration in the filtered supernatant was subsequently determined with a total organic carbon analyzer (TOC-V, Shimadzu Scientific Instruments, Kyoto, Japan). Based on the concentrations of these different $C$ forms determined, the carbon pool index (CPI), carbon pool activity (CPA), carbon pool activity index (CPAI), and carbon pool management index (CPMI) were calculated according to the steps described in Xu et al. [26] and Lou et al. [44] as follows:

Carbon pool index $(\mathrm{CPI})=$ total $\mathrm{C}$ content in the sample $\left(\mathrm{mg} \mathrm{g}^{-1}\right) /$ total $\mathrm{C}$ content in the reference soil sampled from the control $\left(\mathrm{mg} \mathrm{g}^{-1}\right)$

Carbon pool activity $(\mathrm{CPA})=$ Active SOC content $\left(\mathrm{C}_{\mathrm{A}}\right) /$ Non-active SOC content $\left(\mathrm{C}_{\mathrm{NA}}\right)$

where $C_{N A}$ was determined as the difference between total and active SOC (represented by LOC).

Carbon pool activity index $(\mathrm{CPAI})=\mathrm{CPA}$ in the sample $/ \mathrm{CPA}$ in the reference soil

$$
\text { Carbon pool management index }(\mathrm{CPMI})=\mathrm{CPI} \times \mathrm{CPAI} \times 100
$$

The total stocks of various carbon fractions in the top $30 \mathrm{~cm}$ soils were also calculated based on the concentration of SOC fractions, bulk density, and depth [45].

Soil bulk density, salinity, $\mathrm{pH}$, and gravimetric water content were measured following the standard methods [46], while soil total N (TN) concentration was determined by an elemental analyzer (Elementar Vario MAX, Elementar Scientific Instruments, Hanau, Germany). The rate of soil C release (in form of $\mathrm{CO}_{2}$ ) was determined by laboratory incubation [47], through quantifying the change in headspace concentrations over time [43]. The bacterial and fungal population counts were determined by the tablet colony counting method [43].

\subsection{Statistical Analysis}

Statistical analyses in this study were carried out using SPSS 18.0 (SPSS Inc., Chicago, IL, USA). Repeated-measures analysis of variance (RM-ANOVAs) and Bonferroni's post hoc test were used to test for significant differences in total SOC, active SOC fraction, and other soil properties among treatments, with separate analysis for the early and late paddy seasons. The correlations between the concentrations of various SOC fractions and soil properties were examined using Pearson correlation analysis. 


\section{Results}

\subsection{Effect of Waste Amendment on the Concentrations of TOC, Active C Fractions, and C Release Rate}

In the early paddy field, the average soil TOC concentration in the top $30 \mathrm{~cm}$ soil was $36.6 \%$ and $28.7 \%$ greater, respectively, in the treatments of biochar (B) and the steel slag and biochar combination $(\mathrm{SS}+\mathrm{B})$, as compared to the controls $(p<0.05$, Figure 2$)$. Soil LOC concentration was $30.1 \%$ and $25.8 \%$ lower, respectively, in the steel slag (SS) and SS + B treatments than the controls $(p<0.05$, Figure 2$)$. Soil DOC concentration in the SS and SS + B treatments was $28.5 \%$ and $50.3 \%$ higher, respectively, than the controls ( $p<0.05$, Figure 2$)$. Soil $\mathrm{CO}_{2}-\mathrm{C}$ release was $36.9 \%$ lower in the $\mathrm{SS}+\mathrm{B}$ treatment as compared to the controls ( $p<0.05$, Figure 3$)$.
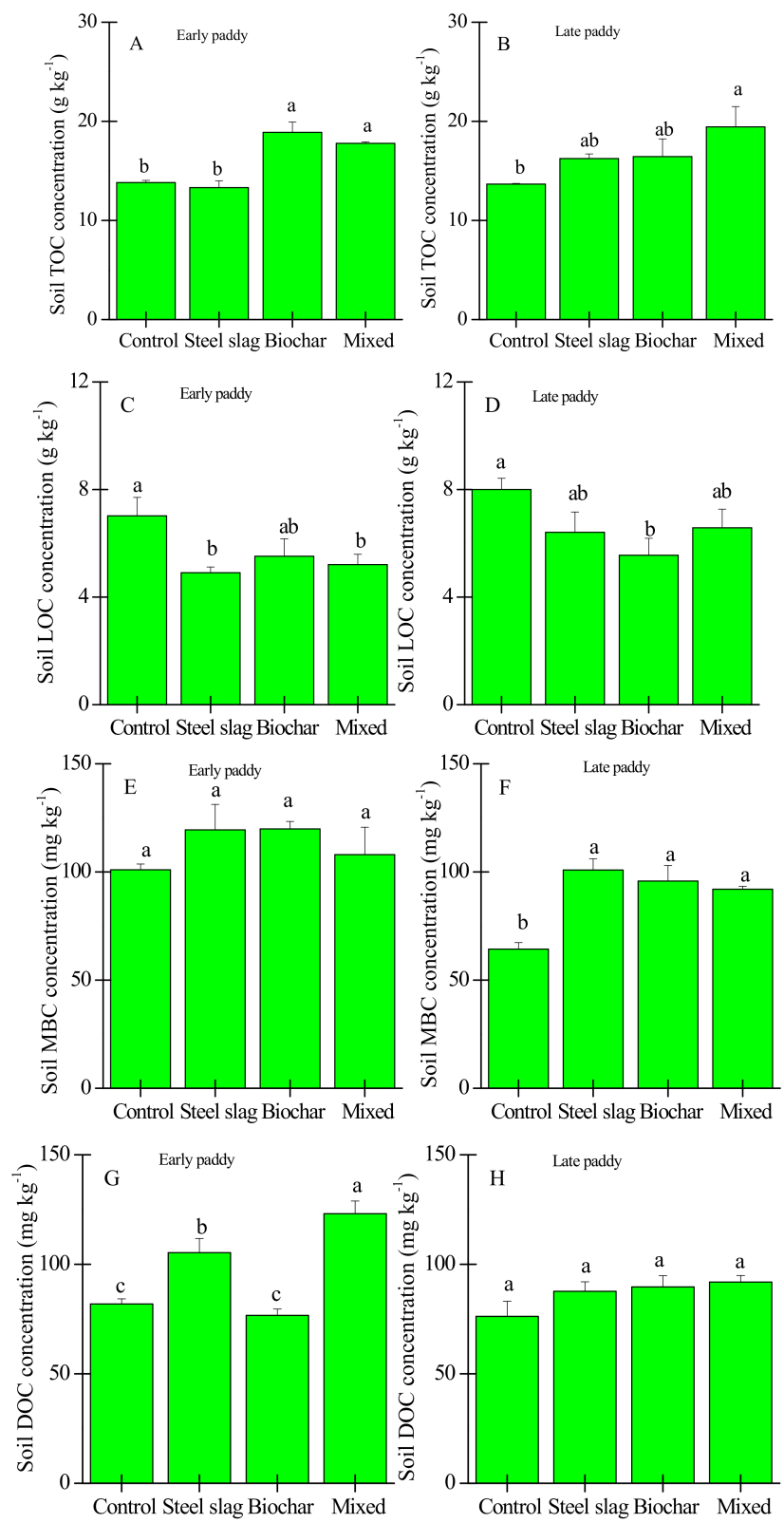

Figure 2. Mean concentrations of SOC $(\mathbf{A}, \mathbf{B}), \operatorname{LOC}(\mathbf{C}, \mathbf{D}), \mathrm{MBC}(\mathbf{E}, \mathbf{F})$, and DOC $(\mathbf{G}, \mathbf{H})$ in the treatment and control plots in the early and late paddy fields. Different letters represent significant difference in mean values among treatments $(p<0.05, n=6)$. 

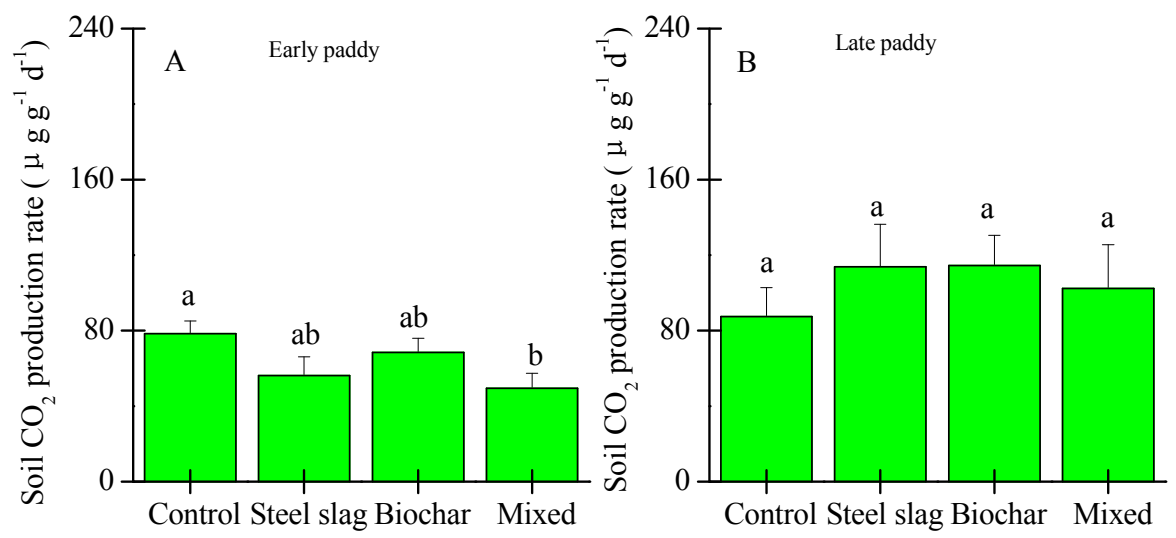

Figure 3. Mean soil $\mathrm{CO}_{2}$ release rates in the treatment and control plots in the early (A) and late paddy fields (B). Different letters represent significant difference in mean values among treatments $(p<0.05$, $n=6)$.

In the late paddy field, the mean soil TOC concentration in the top $30 \mathrm{~cm}$ soil was $42.2 \%$ higher in the SS + B treatment than in the controls $(p<0.05$, Figure 2$)$. When compared to the controls, the mean soil LOC concentration was 30.5\% lower in the B treatment, while the soil MBC concentrations in the SS, B, and SS + B treatments were 56.8\%, 48.9\%, and 43.0\% higher, respectively $(p<0.05$, Figure 2$)$. No differences in soil $\mathrm{CO}_{2}-\mathrm{C}$ release rates were observed among all the treatments $(p>0.05$, Figure 3$)$. Moreover, both the total stock of various soil $C$ fractions and the ratio of soil $C$ fractions to TOC concentrations varied significantly following steel slag and biochar amendments (Figures S2 and S3).

\subsection{Effects of Waste Amendment on Other Soil Properties}

In the early paddy field, the soil bacterial population (colony) count was $65.5 \%, 55.1 \%$, and $51.2 \%$ lower in the SS, B, and SS + B treatments, respectively, as compared to the controls $(p<0.05$, Figure 4$)$. The soil fungal colony was $62.8 \%$ lower in the SS treatment than in the controls $(p<0.05$, Figure 4$)$. The soil fungi:bacteria ratio was $93.1 \%$, and $91.1 \%$ higher in the B and SS + B treatments, respectively, than in the controls $(p<0.05$, Figure 4$)$. In the late paddy field, the soil bacterial colony in the SS and SS + B treatments was $25.1 \%$, and $47.4 \%$ lower, respectively, than in the controls $(p<0.05$, Figure 4). The soil fungal colony was $35.8 \%, 32.9 \%$, and $38.9 \%$ lower in the SS, B, and SS + B treatments, respectively, than in the controls $(p<0.05$, Figure 4$)$. 

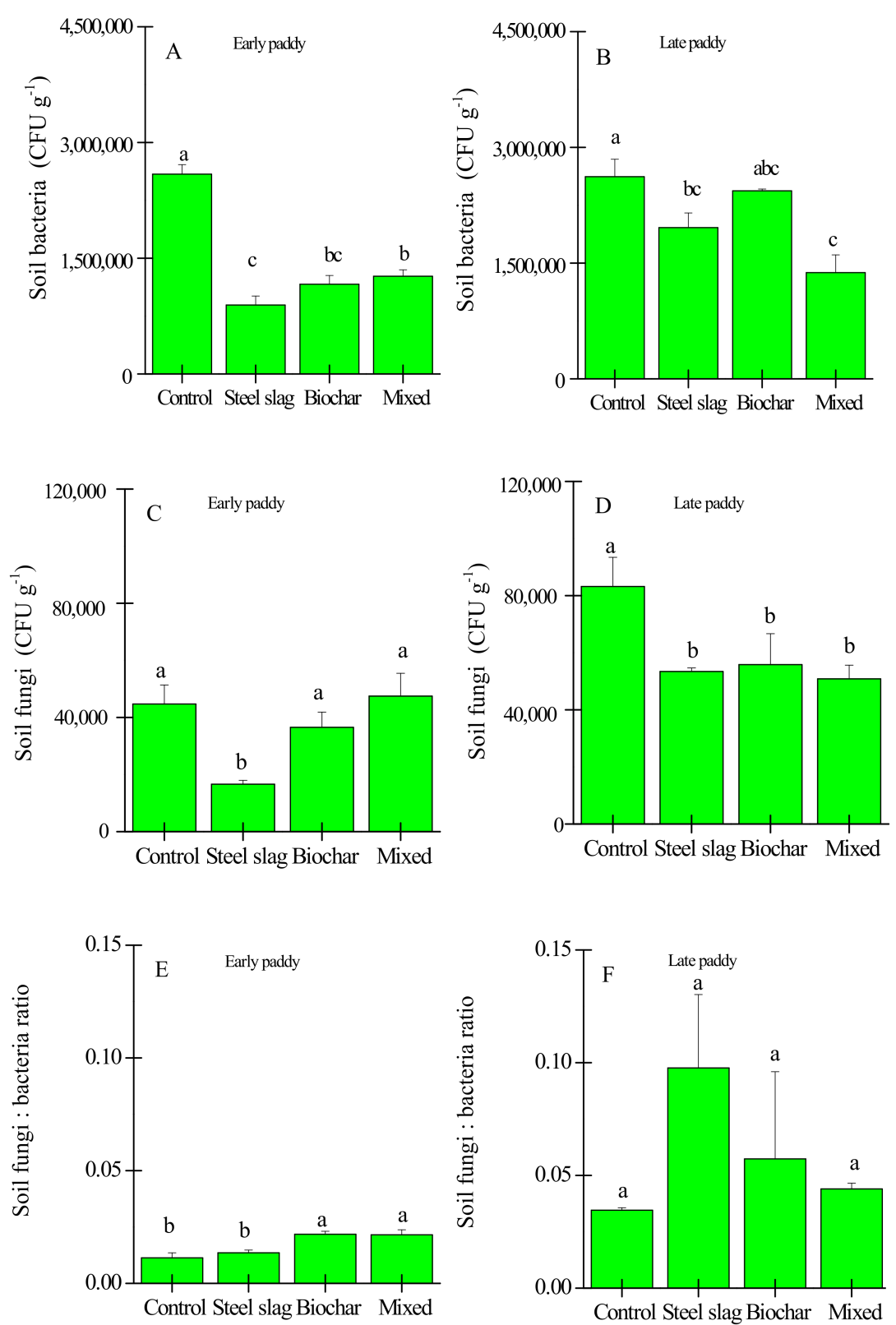

Figure 4. Mean colony count of bacteria (A,B), fungi $(\mathbf{C}, \mathbf{D})$, and fungi:bacteria ratio $(\mathbf{E}, \mathbf{F})$ in the treatment and control plots in the early and late paddy fields. Different letters represent significant difference in mean values among treatments $(p<0.05, n=6)$.

In the early paddy field, soil salinity and $\mathrm{pH}$ in the SS + B treatment were $98.0 \%$ and $14.2 \%$ higher, respectively, than in the controls ( $p<0.05$, Figure 5). Soil N in the B treatment was $10.5 \%$ higher than that in the controls ( $p<0.05$, Figure 5). The soil C:N ratio was $21.6 \%$ and $22.5 \%$ higher in the $\mathrm{B}$ and SS + B treatments, respectively, as compared to the controls $(p<0.05$, Figure 5$)$. In the late paddy field, soil salinity, $\mathrm{pH}$ and the C:N ratio in the SS + B treatments were $108.9 \%, 8.1 \%$ and $29.3 \%$ higher, respectively, than in the controls ( $p<0.05$, Figure 5$)$. The mean soil bulk density in the B plots was $8.6 \%$ lower than that in the controls $(p<0.05$, Figure 5$)$. 

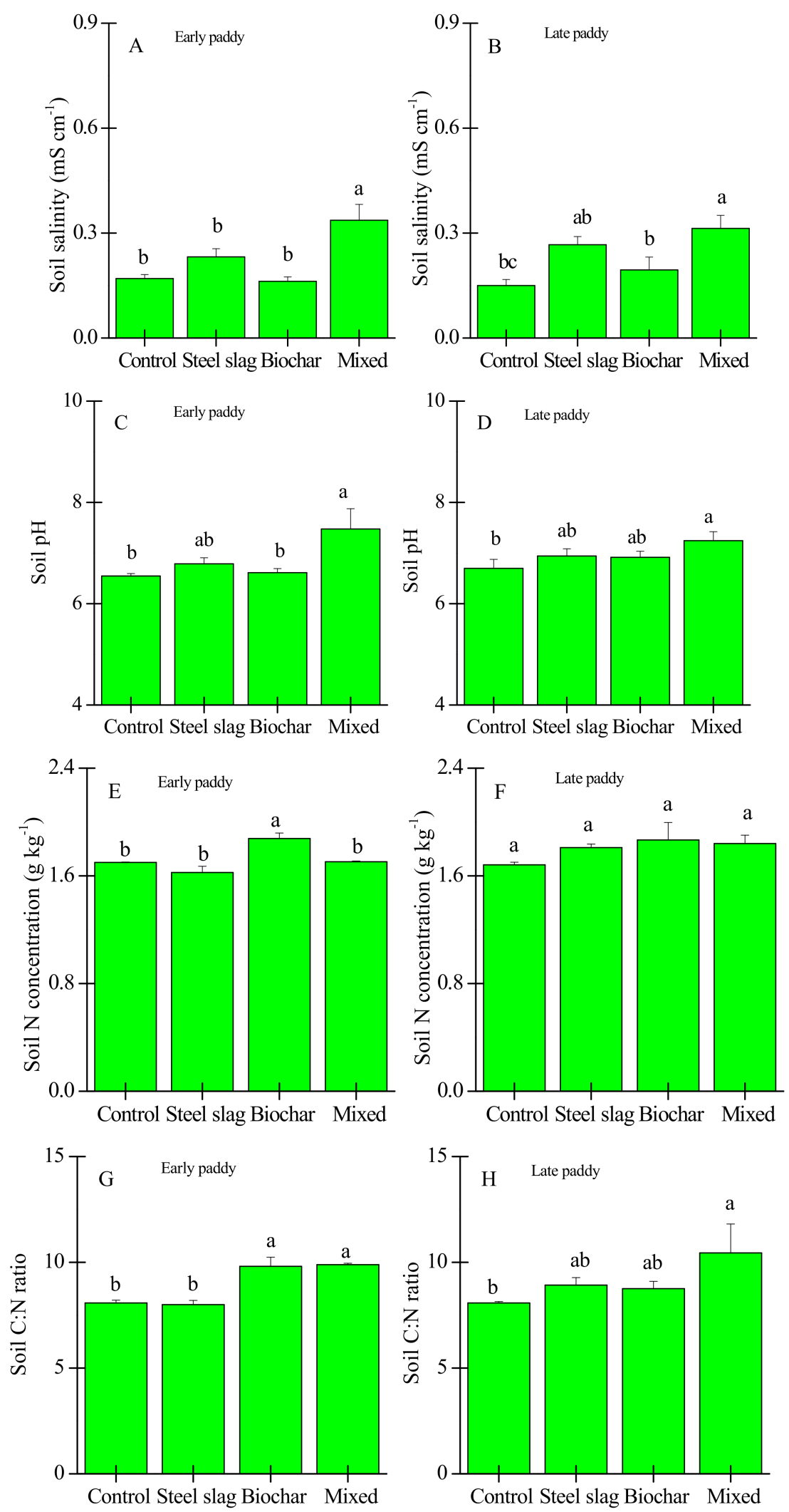

Figure 5. Cont. 

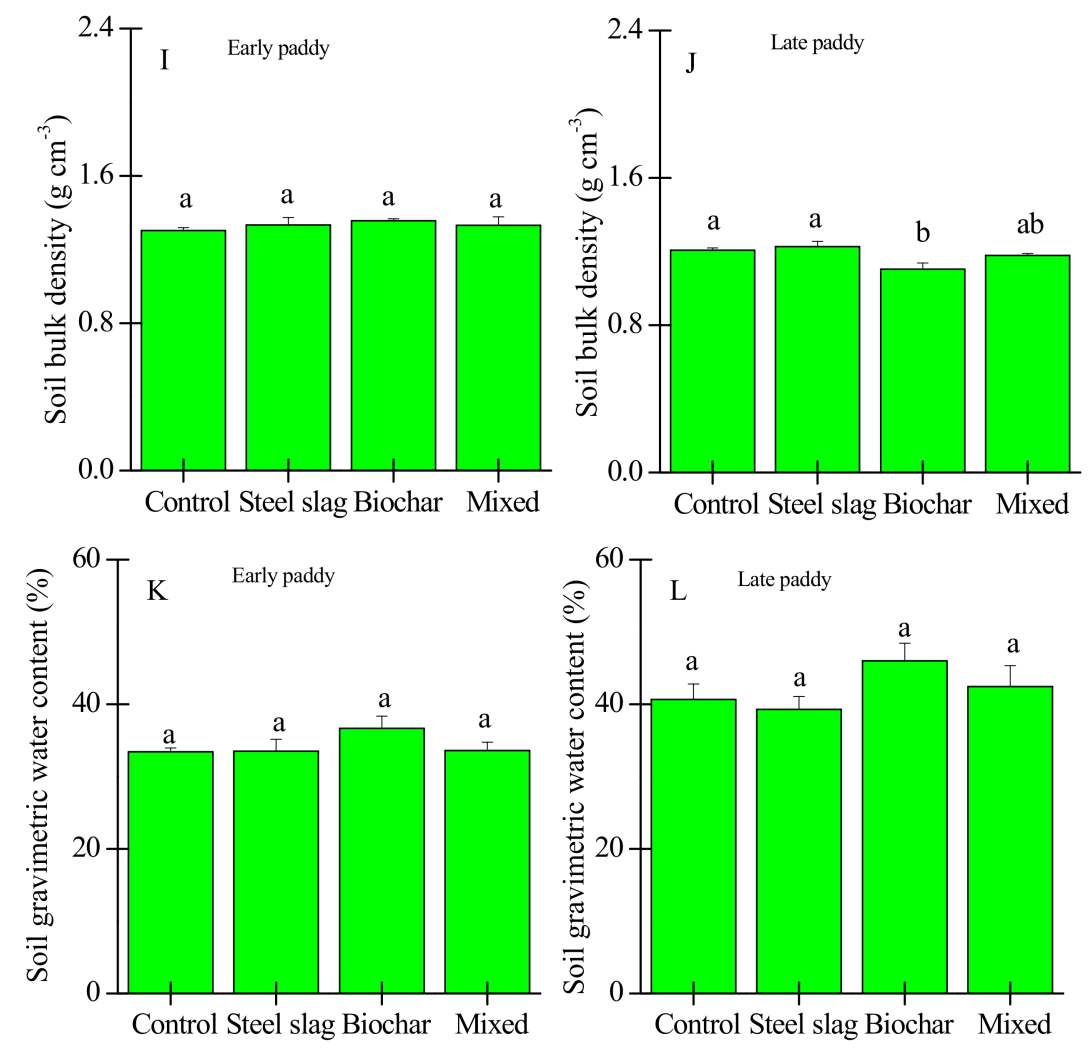

Figure 5. Mean soil salinity (A,B), $\mathrm{pH}(\mathbf{C}, \mathbf{D}), \mathrm{N}$ concentration $(\mathbf{E}, \mathbf{F}), \mathrm{C}: \mathrm{N}$ ratio $(\mathbf{G}, \mathbf{H})$, bulk density $(\mathbf{I}, \mathbf{J})$, and gravimetric water content $(\mathbf{K}, \mathbf{L})$ in the treatment and control plots in the early and late paddy fields. Different letters represent significant difference in mean values among treatments $(p<0.05$, $n=6)$.

\subsection{Relationships between SOC Fractions and Soil Properties}

Table 1 shows the Pearson correlation coefficients between the concentrations of different SOC fractions and the various soil physico-chemical and biological properties. In the early paddy field, the bacterial count was positively correlated with LOC concentration $(r=0.752, p<0.01)$. In addition, soil TOC concentration was positively correlated with soil fungi:bacteria ratio, total $\mathrm{N}$, and C:N ratio $(r=0.845,0.779,0.970$, respectively, $p<0.01)$. Meanwhile, no significant correlations were observed among TOC, DOC, MBC, and LOC concentrations in soils $(p>0.05)$. In the late paddy field, soil TOC concentration was negatively correlated with the bacterial count $(r=-0.518, p<0.05)$, but positively correlated with soil salinity $(r=0.838)$, C:N ratio $(r=0.921)$, and $\mathrm{pH}(r=0.566, p<0.05)$. Negative correlation was found between the fungal count and MBC concentration $(r=-0.582$, $p<0.05)$. Moreover, the soil LOC concentration was negatively correlated with soil MBC concentration $(r=-0.666, p<0.01$, Table S2). When the two paddy fields were combined in the analysis, soil LOC was negatively correlated with both MBC $(r=-0.543, p<0.01)$ and DOC $(r=-0.366, p<0.05$, Table S2). Apart from the concentrations of SOC fractions, the total stocks of various SOC fractions were also significantly correlated with a number of soil properties (Table S3).

\subsection{Effects of Waste Amendment on Soil C Pool Management Index}

Table 2 shows the effects of waste amendment on the active and non-active SOC fractions, as well as the carbon pool management index (CPMI). In the early paddy field, the active SOC fraction $\left(\mathrm{C}_{\mathrm{A}}\right)$ in the SS and SS + B treatments was 30.1\% and $25.8 \%$ lower, respectively, as compared to the controls $(p<$ 0.05). The non-active SOC fraction $\left(C_{N A}\right)$ in the B and SS + B treatments was $96.5 \%$ and $84.9 \%$ higher, respectively, than in the controls $(p<0.05)$. The soil carbon pool activity (CPA) in the B and SS + B 
treatments was $57.5 \%$ and $50.8 \%$ lower, respectively, than in the controls $(p<0.05)$. The soil carbon pool index (CPI) in the B and SS + B treatments was $34.1 \%$ and $22.4 \%$ higher, respectively, than in the controls $(p<0.05)$. The soil carbon pool activity index (CPAI) in the B and SS + B treatments by $55.0 \%$ and 51.2\% lower, respectively, than in the controls $(p<0.05)$. Overall, the soil CPMI in the SS, B, and SS $+\mathrm{B}$ treatments was $36.7 \%, 41.6 \%$, and $45.4 \%$ lower, respectively, as compared to the controls $(p<0.05)$. In the late paddy field, $\mathrm{C}_{\mathrm{A}}$ in the $\mathrm{B}$ treatment was $30.6 \%$ lower than that in the controls $(p<0.05$, Table 2). Soil $\mathrm{C}_{\mathrm{NA}}$ in the SS, B, and SS + B treatments was $73.6 \%, 92.2 \%$, and $126.9 \%$ higher, respectively, than in the controls $(p<0.05)$. As compared to the controls, the soil CPA in the B and SS + B treatments was $55.0 \%$ and $52.6 \%$ lower, respectively $(p<0.05)$. The soil CPI was $40.1 \%$ higher in the SS + B treatment than in the controls $(p<0.05)$. However, we observed no differences in soil CPAI and CPMI among any of our treatments $(p>0.05)$. 
Table 1. Pearson correlation coefficients between the concentrations of different carbon forms and various soil properties.

\begin{tabular}{|c|c|c|c|c|c|c|c|c|c|c|c|}
\hline Stage & C Form & Bacteria & Fungi & Fungi: Bacteria Ratio & Salinity & $\mathrm{pH}$ & Total N & C:N Ratio & Bulk Density & Water Content & C Release \\
\hline \multirow{4}{*}{ Early paddy field } & TOC & -0.275 & 0.443 & $0.845^{* *}$ & 0.191 & 0.314 & 0.779 ** & 0.970 ** & 0.161 & 0.346 & -0.125 \\
\hline & LOC & $0.752 * *$ & 0.361 & -0.347 & -0.391 & -0.381 & 0.025 & -0.115 & -0.012 & -0.436 & $0.614 *$ \\
\hline & $\mathrm{MBC}$ & -0.479 & 0.357 & 0.227 & -0.251 & -0.106 & 0.016 & 0.188 & $0.592 *$ & -0.121 & -0.256 \\
\hline & DOC & -0.367 & -0.028 & 0.150 & $0.849^{* *}$ & $0.791^{* *}$ & -0.422 & 0.196 & -0.069 & -0.264 & $-0.614^{*}$ \\
\hline \multirow{4}{*}{ Late paddy field } & TOC & $-0.518^{*}$ & -0.332 & 0.320 & $0.838^{* *}$ & $0.566^{*}$ & 0.442 & $0.921 * *$ & -0.340 & 0.235 & 0.436 \\
\hline & LOC & 0.296 & 0.382 & -0.159 & -0.084 & 0.011 & $-0.636 *$ & 0.205 & 0.374 & -0.260 & -0.056 \\
\hline & $\mathrm{MBC}$ & -0.352 & $-0.582 *$ & 0.175 & 0.467 & 0.357 & 0.410 & 0.252 & -0.279 & 0.161 & 0.379 \\
\hline & DOC & -0.318 & -0.418 & 0.323 & 0.313 & 0.139 & 0.328 & 0.262 & 0.138 & 0.301 & -0.071 \\
\hline \multirow{4}{*}{$\begin{array}{l}\text { Combined paddy } \\
\text { field }\end{array}$} & TOC & -0.301 & 0.063 & 0.302 & $0.520 * *$ & $0.407 *$ & 0.583 ** & 0.933 ** & -0.145 & 0.243 & 0.244 \\
\hline & LOC & $0.605^{* *}$ & $0.506^{* *}$ & 0.102 & -0.197 & -0.147 & -0.202 & 0.091 & -0.202 & 0.101 & $0.358 *$ \\
\hline & $\mathrm{MBC}$ & $-0.570 * *$ & $-0.675 * *$ & -0.250 & 0.060 & -0.014 & -0.008 & 0.150 & $0.553^{* *}$ & -0.434 * & -0.308 \\
\hline & DOC & -0.434 * & -0.308 & -0.058 & $0.601 * *$ & $0.565^{* *}$ & -0.216 & 0.170 & 0.214 & -0.244 & $-0.416^{*}$ \\
\hline
\end{tabular}

${ }^{*}$ significant at $p<0.05,{ }^{* *}$ significant at $p<0.01$. Note: TOC: Total organic carbon; LOC: Labile organic carbon; MBC: Microbial biomass carbon; DOC: Dissolved organic carbon.

Table 2. Effects of waste amendment on the soil carbon pool management index and crop yield.

\begin{tabular}{|c|c|c|c|c|c|c|c|c|}
\hline Stage & Treatment & $\mathrm{C}_{\mathrm{A}}\left(\mathrm{mg} \cdot \mathrm{g}^{-1}\right)$ & $\mathrm{C}_{\mathrm{NA}}\left(\mathrm{mg} \cdot \mathrm{g}^{-1}\right)$ & CPA & CPI & CPAI & CPMI & Crop Yield $\left(\mathrm{Mg} \mathrm{ha}^{-1}\right)$ \\
\hline \multirow{4}{*}{$\begin{array}{l}\text { Early Paddy } \\
\text { field }\end{array}$} & Control & $7.02 \pm 0.68 \mathrm{a}$ & $6.80 \pm 0.66 \mathrm{~b}$ & $1.09 \pm 0.22 \mathrm{a}$ & $1.00 \pm 0.00 \mathrm{c}$ & $1.00 \pm 0.00 \mathrm{a}$ & $100.00 \pm 0.00 \mathrm{a}$ & $4.63 \pm 0.64 \mathrm{a}$ \\
\hline & Steel slag & $4.91 \pm 0.21 \mathrm{~b}$ & $8.41 \pm 0.86 \mathrm{~b}$ & $0.78 \pm 0.10 \mathrm{ab}$ & $0.94 \pm 0.02 c$ & $0.71 \pm 0.06 \mathrm{a}$ & $63.30 \pm 6.76 b$ & $4.67 \pm 0.20 \mathrm{a}$ \\
\hline & Biochar & $5.52 \pm 0.65 \mathrm{ab}$ & $13.36 \pm 0.62 \mathrm{a}$ & $0.47 \pm 0.06 b$ & $1.34 \pm 0.06 \mathrm{a}$ & $0.45 \pm 0.10 \mathrm{~b}$ & $58.36 \pm 10.61 \mathrm{~b}$ & $4.91 \pm 0.52 \mathrm{a}$ \\
\hline & Steel slag + biochar & $5.21 \pm 0.39 \mathrm{~b}$ & $12.57 \pm 0.40 \mathrm{a}$ & $0.54 \pm 0.08 \mathrm{~b}$ & $1.22 \pm 0.03 \mathrm{~b}$ & $0.49 \pm 0.02 \mathrm{~b}$ & $54.55 \pm 4.47 \mathrm{~b}$ & $5.06 \pm 0.26 a$ \\
\hline \multirow{4}{*}{$\begin{array}{l}\text { Late Paddy } \\
\text { field }\end{array}$} & Control & $8.00 \pm 0.41 \mathrm{a}$ & $5.67 \pm 0.46 \mathrm{~b}$ & $1.50 \pm 0.21 \mathrm{a}$ & $1.00 \pm 0.00 \mathrm{~b}$ & $1.00 \pm 0.00 \mathrm{a}$ & $100.00 \pm 0.00 \mathrm{a}$ & $6.73 \pm 0.94 \mathrm{a}$ \\
\hline & Steel slag & $6.41 \pm 0.75 \mathrm{ab}$ & $9.84 \pm 0.30 \mathrm{a}$ & $0.91 \pm 0.35 \mathrm{ab}$ & $1.20 \pm 0.03 \mathrm{ab}$ & $0.67 \pm 0.33 \mathrm{a}$ & $82.30 \pm 42.28 a$ & $6.83 \pm 0.19 a$ \\
\hline & Biochar & $5.56 \pm 0.63 \mathrm{~b}$ & $10.89 \pm 1.92 \mathrm{a}$ & $0.68 \pm 0.22 b$ & $1.22 \pm 0.14 \mathrm{ab}$ & $0.45 \pm 0.14 \mathrm{a}$ & $53.90 \pm 15.01 \mathrm{a}$ & $6.97 \pm 0.21 \mathrm{a}$ \\
\hline & Steel slag + biochar & $6.58 \pm 0.69 \mathrm{ab}$ & $12.86 \pm 1.41 \mathrm{a}$ & $0.71 \pm 0.14 b$ & $1.40 \pm 0.12 \mathrm{a}$ & $0.50 \pm 0.16 \mathrm{a}$ & $67.91 \pm 24.04 \mathrm{a}$ & $7.20 \pm 0.14 \mathrm{a}$ \\
\hline
\end{tabular}

Different letters in a given column represent significant difference in mean values among treatments in a given stage at $p<0.05$. $C_{A}$ : Active soil organic carbon content; $C_{N A}$ : Non-active soil organic carbon content; CPA: Carbon pool activity; CPI: Carbon pool index; CPAI: Carbon pool activity index; CPMI: Carbon pool management index. 


\section{Discussion}

\subsection{Effects of Waste Amendment on Soil Properties}

The combined application of steel slag and biochar significantly increased soil salinity in both the early and late paddy fields, while the addition of biochar or steel slag alone caused a slight but insignificant increase in soil salinity. The steel slag and biochar used in this study contained numerous macro- and micro-nutrients, including N, P, K, Ca, and Si [12,13]. Subsequent to their amendment in soils, many of the cation nutrients were released back into the soil solution, which in turn led to an elevation in soil salinity [14]. When both steel slag and biochar were applied together, significantly higher soil $\mathrm{pH}$ was observed in both the early and late paddy fields as compared to the controls, which could be a result of the gradual release of ions from rich alkaline substances (e.g., N, P, K, Ca, and Si) present in the amendment materials into the soils $[1,12,14,48]$.

The combined use of steel slag and biochar also increased soil C:N ratios, favoring a greater sequestration of $\mathrm{C}$ than $\mathrm{N}$ in soils which was expected following the introduction of $\mathrm{C}$-rich biochar [12]. The soil bacterial and fungal counts were significantly lower in the SS, B, and SS + B treatments in both the early and late paddy fields, which could be attributed in part to the release of ethylene from biochar that inhibited bacterial and fungal activities, and subsequently reduced their population size $[49,50]$. Moreover, the presence of biochar could suppress organic matter decomposition owing to its impact in reducing the temperature sensitivity and activation energy of soil carbon mineralization [51]. Biochar could contribute to an increase in soil $C$ stability by protecting the $C$ from bacterial and fungal decomposition as well as limiting the responses of $\mathrm{C}$ in both biochar and native soils to temperature [51,52]. On the other hand, steel slag was rich in ferric oxide $\left(\mathrm{Fe}_{2} \mathrm{O}_{3}\right)$ that could form a tight bonding with $\mathrm{C}$, thereby improving the stability of $\mathrm{C}$ in soils through reduced availability of labile $\mathrm{C}$ for bacterial and fungal activities [53]. Meanwhile, the soil fungi:bacteria ratio showed a slight increase with the addition of soil amendments, which implied that fungi had a higher $\mathrm{C}$ use efficiency than bacteria [54]. Furthermore, a previous study showed that the application of steel slag in paddy fields had no significant impacts on heavy metal concentrations in soils but improved rice yield considerably owing to an enhanced nutrient supply, in spite of an increase in soil salinity [14].

\subsection{Effects of Waste Amendment on Soil Active SOC Fractions and C:N Ratio}

Our results showed that the combined application of steel slag and biochar significantly increased the total SOC concentrations in both early and late paddy fields. The introduction of exotic biochar would directly increase the amount of $C$ input to the system and thus the $C$ concentration in soils [10]. Moreover, biochar could effectively reduce gaseous $C$ emissions in form of $\mathrm{CO}_{2}[19,50]$ and enhance $\mathrm{C}$ storage in soils by protecting soil $\mathrm{C}$ from microbial attack and attenuating the temperature sensitivity of soil C decomposition [55-57]. On the other hand, steel slag was very rich in ferric oxide $[13,14]$ that could help minimize the release of soil $\mathrm{C}$ in form of methane $\left(\mathrm{CH}_{4}\right)$ [14] and increase soil $\mathrm{C}$ storage $[1,48,58]$. We also found that total SOC concentration was significantly and positively correlated with soil salinity when data from the two paddy fields were combined in the analysis, which was in agreement with the findings of a previous study conducted in a natural wetland close to our study site [47]. A higher salinity in soils could suppress microbial activity [59,60], including the microbial-mediated production of greenhouse gases (e.g., $\mathrm{CH}_{4}$ and $\mathrm{CO}_{2}$ ) and their subsequent release into the atmosphere [61-63].

The application of waste amendments was also found to increase the soil C:N ratio. A higher $\mathrm{C}: \mathrm{N}$ ratio was typically associated with a lower $\mathrm{N}$ availability to microbes, which would suppress organic matter mineralization and $\mathrm{CO}_{2}$ emissions while at the same time increase the stability of $\mathrm{MBC}$ and the sequestration of soil $C[20,63]$. The increase in total SOC concentrations in response to the addition of waste amendments might also be related to the changes in soil $\mathrm{N}$ concentrations. In our study, the concentration of total SOC was found to be significantly and positively correlated with that of total $\mathrm{N}$, implying that $\mathrm{N}$ was the limiting nutrient for rice growth in the paddy fields. The soils in 
our treatment plots had slightly higher total $\mathrm{N}$ concentrations than in the controls, which could result in greater SOC concentrations in the former, as the $\mathrm{C}$ and $\mathrm{N}$ cycles were tightly coupled and affected by $\mathrm{N}$ supply in paddy fields $[27,33,34]$. A previous study showed that soils in paddy fields converted from natural wetlands had much lower $\mathrm{N}$ concentrations as compared to those in adjacent natural wetlands, even after the application of a substantial amount of nitrogenous fertilizers, owing to the severe $\mathrm{N}$ limitation in these paddy soils [45]. In addition, the increase in fungal to bacterial population ratio had important implications to soil $\mathrm{C}$ sequestration. As the growth efficiency of fungi was higher than that of bacteria, the fungi-dominated microbial community associated with a high fungi:bacteria ratio could stimulate a greater soil $\mathrm{C}$ storage, improve soil $\mathrm{C}$ stability, and reduce $\mathrm{CO}_{2}$ emission from soils to the atmosphere [54]. Furthermore, an increase in crop yield and rice biomass as a result of waste amendment might also contribute to an enhanced input of organic matter into soils [26].

\subsection{Effects of Waste Amendment on Soil CPMI}

The CPMI and the related indices are commonly used in soil management for agricultural land use practices [26,36]. They are useful for identifying the response of SOC to changes in environmental conditions and management practices, as well as providing an integrated measure of SOC quantity and quality for assessing soil fertility [26]. There is at present a paucity of studies examining the impacts of applying exogenous carbon such as biochar on soil CPMI, which deserves further investigation. In our study, the CPMI was significantly lower in treatments amended with steel slag and biochar, either alone or in combination, during the early paddy field, which indicated a lower active soil $\mathrm{C}$ pool and a lower capacity of soil nutrient storage for crop growth. The lower concentration of active SOC fraction (i.e., LOC) observed in the amended treatment suggested that the rates of organic matter decomposition and nutrient cycling were low, reducing the conversion of nutrients in organic to inorganic forms through mineralization for plant growth. In the future management of paddy fields, the amount of waste materials applied should be optimized to increase soil C sequestration while safeguarding adequate nutrient supply. The decrease in CPMI following waste application was consistent to the reduction in the values of $\mathrm{C}_{\mathrm{NA}}, \mathrm{CPA}, \mathrm{CPI}$, and CPAI observed in our site, which all pointed to an increase in SOC stability and storage capability in soils. There were numerous reasons that could possibly account for the enhanced stability of SOC stability after the application of steel slag and/or biochar. A previous study conducted in the same experimental site demonstrated an increase in the formation and stability of macro-aggregates in soils following the applications of steel slag and biochar [64]. The presence of these soil aggregates is crucial in providing physical protection to SOC from microbial attacks. Also, chemical bonding established between ferric oxide and SOC was another important protection mechanism of soil C [53]. The addition of steel slag in our study increased the soil ferric oxide concentrations [1], which could form more bonds with SOC to improve $\mathrm{C}$ stability. Biochar could exert similar impacts on SOC stability through enhancing the supply of ferric oxide to soils. Moreover, the regulation of microbial activities play a role in governing SOC decomposition and stability. As discussed earlier, the increase in fungi:bacteria ratio following waste amendments could promote a greater soil $\mathrm{C}$ storage owing to a greater growth efficiency of fungi that contributed to $C$ sequestration [54]. Furthermore, since the C-rich biochar is derived from pyrolysed agricultural wastes such as straw, it possesses chemical properties that increase the resistance of $C$ to decomposition, and subsequently reduce the emissions of $\mathrm{CO}_{2}-\mathrm{C}$ from soils [55]. The greater SOC stability in response to biochar amendment was probably a result of the presence of different aromatic forms of $C$ in biochar, which would increase the soil humin $C$ ratio, stimulate the formation of soil macro- aggregates, and enhance the stability of SOC both physically and chemically [52].

\section{Conclusions}

The steel slag produced as an industrial by-product and the biochar produced from agricultural wastes may be used as soil amendments with the potential to improve soil quality by enhancing soil $\mathrm{C}$ sequestration. We observed that SOC concentrations in the top $30 \mathrm{~cm}$ soils of SS + B treatment were 
$28.7 \%$ and $42.2 \%$ higher in the early and late crops, respectively, as compared with controls, which was positively related to the increase in soil C:N ratio. As compared to the controls, the soil non-active SOC fraction was significantly higher in both B and SS + B treatments by $84.9-96.5 \%$ and $92.2-126.9 \%$, respectively, while the carbon pool index was significantly higher in the SS + B treatment by 22.4 and $40.1 \%$ in the early and late crops, respectively. In the early crop, the CPAI was significantly lower in B and SS + B treatments by over 50\% than in the control, while the CPMI in the SS, B, and SS + B treatments was lower than that in the control by $36.7 \%, 41.6 \%$, and $45.4 \%$, respectively. However, we observed no significant differences in both CPAI and CPMI among the treatments during the late crop. Our findings suggest that the addition of steel slag and biochar in subtropical paddy fields could contribute to a greater soil $\mathrm{C}$ sequestration by causing a drop in the active SOC pools during the early paddy season.

Supplementary Materials: The following are available online at http:/ /www.mdpi.com/2073-4395/8/8/135/s1, Figure S1: Temporal variations of air temperature (A) and rainfall (B) in the study area, Figure S2: Mean ratios of LOC:TOC $(A, B)$, MBC:TOC $(C, D)$, and DOC:TOC $(E, F)$ in the treatment and control plots in the early and late paddy fields. Different letters represent significant difference in mean values among treatments $(p<0.05, n=6)$, Figure S3: Mean total stocks of SOC $(\mathrm{A}, \mathrm{B}), \mathrm{LOC}(\mathrm{C}, \mathrm{D}), \mathrm{MBC}(\mathrm{E}, \mathrm{F})$, and $\mathrm{DOC}(\mathrm{G}, \mathrm{H})$ in the treatment and control plots in the early and late paddy fields. Different letters represent significant difference in mean values among treatments $(p<0.05, n=6)$, Table S1: Characteristics of steel slag and biochar used in this study, Table S2: Pearson correlation coefficients between soil organic carbon fractions, Table S3: Pearson correlation coefficients between the total stocks of different carbon forms and various soil properties.

Author Contributions: W.W., X.X. and C.W. designed the experiment; W.W. and C.W. performed the experiment; W.W., D.Y.F.L., A.A.A., S.N. provided data analyses; and W.W., D.Y.F.L., A.A.A., S.N. and X.X. co-wrote the paper.

Funding: Funding was provided by the National Science Foundation of China $(41571287 ; 31000209)$, Research Project of Public Institute of Fujian Province (2018R1034-1), and Outstanding Young Research Talents in Higher Education of Fujian Province (2017).

Acknowledgments: The authors would like to thank Miaoying Wang, Guixiang Chen, Wanli An, Xiaoting Huang, Xu Song for their assistance with field sampling.

Conflicts of Interest: The authors declare no conflict of interest.

\section{References}

1. Wang, W.; Sardans, J.; Lai, D.Y.F.; Wang, C.; Zeng, C.; Tong, C.; Liang, Y.; Peñuelas, J. Effects of steel slag application on greenhouse gas emissions and crop yield over multiple growing seasons in a subtropical paddy field in China. Field Crop. Res. 2015, 171, 146-156. [CrossRef]

2. Frolking, S.; Qiu, J.; Boles, S.; Xiao, X.; Liu, J.; Zhuang, Y.; Li, C.; Qin, X. Combining remote sensing and ground census data to develop new maps of the distribution of rice agriculture in China. Glob. Biogeochem. Cycle 2002, 16, 1091-1101. [CrossRef]

3. Hou, H.; Peng, S.; Xu, J.; Yang, S.; Mao, Z. Seasonal variations of $\mathrm{CH}_{4}$ and $\mathrm{N}_{2} \mathrm{O}$ emissions in response to water management of paddy fields located in Southeast China. Chemosphere 2012, 89, 884-892. [CrossRef] [PubMed]

4. Fageria, N.K. Yield physiology of rice. J. Plant Nutr. 2007, 30, 843-879. [CrossRef]

5. Food and Agricultural Organization of the United Nations (FAO). OECD-FAO Agricultural Outlook 2011-2030. 2009. Available online: http:/ / aii.caas.net.cn/AgriOutlook/pdf/3-B3.Stefania\%20Vannuccini_ OECD-FAO\%20Agricultural\%20Outlook\%202013-2022_China\%20Fish\%20Outlook.pdf (accessed on 28 May 2018).

6. Pan, G.; Li, L.; Wu, L.; Zhang, X. Storage and sequestration potential of topsoil organic carbon in China's paddy soils. Glob. Chang. Biol. 2004, 10, 79-92. [CrossRef]

7. Lal, R. Soil carbon sequestration impacts on global climate change and food security. Science 2004, 304, 1623-1627. [CrossRef] [PubMed]

8. Zhou, Y.R.; Yu, Z.L.; Zhao, S.D. arbon storage and budget of major Chinese forest types. Acta Phytoecol. Sin. 2000, 24, 518-522.

9. Ni, J. Carbon storage in grasslands of China. J. Arid Environ. 2002, 50, 205-218. [CrossRef] 
10. Wissing, L.; Kölbl, A.; Vogelsang, V.; Fu, J.; Cao, Z.; Kögel-Knabner, I. Organic carbon accumulation in a 2000-year chronosequence of paddy soil evolution. Catena 2011, 87, 376-385. [CrossRef]

11. Wang, W.; Lai, D.Y.F.; Wang, C.; Pan, T.; Zeng, C. Effects of rice straw incorporation on active soil organic carbon pools in a subtropical paddy field. Soil Till. Res. 2015, 152, 8-16. [CrossRef]

12. Zhang, A.; Cui, L.; Pan, G.; Li, L.; Hussain, Q.; Zhang, X.; Zheng, J.; Crowley, D. Effect of biochar amendment on yield and methane and nitrous oxide emissions from a rice paddy from Tai Lake plain, China. Agric. Ecosyst. Environ. 2010, 139, 469-475. [CrossRef]

13. Wang, W.; Li, P.; Zeng, C.; Tong, C. Evaluation of silicate iron slag as a potential methane mitigating method. Adv. Mater. Res. 2012, 468, 1626-1630. [CrossRef]

14. Wang, W.; Lai, D.Y.F.; Li, S.; Kim, P.J.; Zeng, C.; Li, P.; Liang, Y. Steel slag amendment reduces methane emission and increases rice productivity in subtropical paddy fields in China. Wetl. Ecol. Manag. 2014, 22, 683-691. [CrossRef]

15. Sohi, S.P.; Krull, E.; Lopez-Capel, E.; Bol, R. A review of biochar and its use and function in soil. Adv. Agron. 2010, 105, 47-82.

16. Lehmann, J. A handful of carbon. Nature 2007, 447, 143-144. [CrossRef] [PubMed]

17. Spokas, K.A.; Cantrell, K.B.; Novak, J.M.; Archer, D.W.; Ippolito, J.A.; Collins, H.P.; Boateng, A.A.; Lima, I.M.; Lamb, M.C.; McAloon, A.J.; et al. Biochar: A synthesis of its agronomic impact beyond carbon sequestration. J. Environ. Qual. 2012, 41, 973-989. [CrossRef] [PubMed]

18. Furukawa, Y.; Inubushi, K. Feasible suppression technique of methane emission from paddy soil by iron amendment. Nutr. Cycl. Agroecosyst. 2002, 64, 193-201. [CrossRef]

19. Spokas, K.A.; Koskinen, W.C.; Baker, J.M.; Reicosky, D.C. Impacts of woodchip biochar additions on greenhouse gas production and sorption/degradation of two herbicides in a Minnesota soil. Chemosphere 2009, 77, 574-581. [CrossRef] [PubMed]

20. Liu, Y.; Yang, M.; Wu, Y.; Wang, H.; Chen, Y.; Wu, W. Reducing $\mathrm{CH}_{4}$ and $\mathrm{CO}_{2}$ emissions from waterlogged paddy soil with biochar. J. Soil. Sediment. 2011, 11, 930-939. [CrossRef]

21. Kimura, M.; Murase, J.; Lu, Y. Carbon cycling in rice field ecosystems in the context of input, decomposition and translocation of organic materials and the fates of their end products $\left(\mathrm{CO}_{2}\right.$ and $\left.\mathrm{CH}_{4}\right)$. Soil. Biol. Biochem. 2004, 36, 1399-1416. [CrossRef]

22. Chen, H.L.; Zhou, J.M.; Xiao, B.H. Characterization of dissolved organic matter derived from rice straw at different stages of decay. J. Soil Sediment. 2010, 10, 915-922. [CrossRef]

23. Purakayastha, T.J.; Rudrappa, L.; Singh, D.; Swarup, A.; Bhadraray, S. Long-term impact of fertilizers on soil organic carbon pools and sequestration rates in maize-wheat-cowpea cropping system. Geoderma 2008, 144, 370-378. [CrossRef]

24. Gong, W.; Yan, X.; Wang, J.; Hu, T.; Gong, Y. Long-term manuring and fertilization effects on soil organic carbon pools under a wheat-maize cropping system in North China Plain. Plant Soil 2009, 149, 318-324. [CrossRef]

25. Xu, R.; Zhao, A.; Yuan, J.; Jiang, J. pH buffering capacity of acid soils from tropical and subtropical regions of China as influenced by incorporation of crop straw biochars. J. Soil Sediment. 2012, 12, 494-502. [CrossRef]

26. Xu, M.; Lou, Y.; Sun, X.; Wang, W.; Baniyamuddin, M.; Zhao, K. Soil organic carbon active fractions as early indicators for total carbon change under straw incorporation. Biol. Fert. Soils 2011, 47, 745-752. [CrossRef]

27. Bhattacharyya, P.; Nayak, A.K.; Mohanty, S.; Tripathi, R.; Mohammad, S.; Anjani, K.; Raja, R.; Panda, B.B.; Roy, K.S.; Neogi, S.; et al. Greenhouse gas emission in relation to labile soil C, N pools and functional microbial diversity as influenced by 39 years long-term fertilizer management in tropical rice. Soil Till. Res. 2013, 129, 93-105. [CrossRef]

28. Srinivasarao, C.; Venkateswarlu, B.; Lal, R.; Singh, A.K.; Kundu, S.; Vittal, K.P.R.; Patel, J.J.; Patel, M.M. Long-term manuring and fertilizer effects on depletion of soil organic carbon stocks under pearl millet-cluster bean-castor rotation in Western India. Land Degrad. Dev. 2014, 25, 173-183. [CrossRef]

29. Neogi, S.; Bhattacharyya, P.; Roy, K.S.; Panda, B.B.; Nayak, A.K.; Rao, K.S.; Manna, M.C. Soil respiration, labile carbon pools and enzyme activities as affected by tillage practices in a tropical rice-maize-cowpea cropping system. Environ. Monit. Assess. 2014, 186, 4223-4236. [CrossRef] [PubMed]

30. Chai, Q.; Qin, A.Z.; Gan, Y.T.; Yu, A.Z. Higher yield and lower carbon emission by intercropping maize with rape, pea, and wheat in arid irrigation areas. Agron. Sustain. Dev. 2013, 34, 535-543. [CrossRef] 
31. Gan, Y.; Liang, C.; Chai, Q.; Lemke, R.L.; Campbell, C.A.; Zentner, R.P. Improving farming practices reduces the carbon footprint of spring wheat production. Nat. Commun. 2014, 5, 6012. [CrossRef] [PubMed]

32. Knoblauch, C.; Maarifat, A.A.; Pfeiffer, E.M.; Faefele, S.M. Degradability of black carbon and its impact on trace gas fluxes and carbon turnover in paddy soils. Soil Biol. Biochem. 2011, 43, 1768-1778. [CrossRef]

33. Bhattacharyya, P.; Roy, K.S.; Neogi, S.; Adhya, T.K.; Rao, K.S.; Manna, M.C. Effects of rice straw and nitrogen fertilization on greenhouse gas emissions and carbon storage in tropical flooded soil planted with rice. Soil Till. Res. 2012, 124, 119-130. [CrossRef]

34. Bhattacharyya, P.; Roy, K.S.; Neogi, S.; Chakravorti, S.P.; Behera, K.S.; Das, K.M.; Bardhan, S.; Rao, K.S. Effect of long term application of organic amendment on $\mathrm{C}$ storage in relation to global warming potential and biological activities in tropical flooded soil planted to rice. Nutr. Cycl. Agroecosyst. 2012, 94, 273-285. [CrossRef]

35. Hanke, A.; Cerli, C.; Muhr, J.; Borken, W.; Kalbitz, K. Redox control on carbon mineralization and dissolved organic matter along a chronosequence of paddy soils. Eur. J. Soil Sci. 2013, 64, 476-487. [CrossRef]

36. Blair, N.; Faulkner, R.D.; Till, A.R.; Poulton, P.R. Long-term management impactions on soil C, N and physical fertility. Part I: Broadbalk experiment. Soil Till. Res. 2006, 91, 30-38. [CrossRef]

37. Zhao, F.; Yang, G.; Han, X.; Feng, Y.; Ren, G. Stratification of carbon fractions and carbon management index in deep soil affected by the Grain-to-Green Program in China. PLoS ONE 2014, 9, e99657. [CrossRef] [PubMed]

38. Myhre, G.; Shindell, D.; Bréon, F.M.; Collins, W.; Fuglestvedt, J.; Huang, J.; Koch, D.; Lamarque, J.F.; Lee, D.; Mendoza, B.; et al. Anthropogenic and Natural Radiative Forcing. In Climate Change 2013: The Physical Science Basis; Contribution of Working Group I to the Fifth Assessment Report of the Intergovernmental Panel on Climate Change; Stocker, T.F., Qin, D., Plattner, G.K., Tignor, M., Allen, S.K., Boschung, J., Nauels, A., Xia, Y., Bex, V., Midgley, P.M., Eds.; Cambridge University Press: Cambridge, UK; New York, NY, USA, 2013.

39. Ali, M.A.; Oh, J.H.; Kim, P.J. Evaluation of silicate iron slag amendment on reducing methane emission from flood water rice farming. Agric. Ecosyst. Environ. 2008, 128, 21-26. [CrossRef]

40. Ali, M.A.; Lee, C.H.; Kim, P.J. Effect of silicate fertilizer on reducing methane emission during rice cultivation. Biol. Fert. Soils 2008, 44, 597-604. [CrossRef]

41. Chung, H.; Ngo, K.J.; Plante, A.; Six, J. Evidence for carbon saturation in a highly structured and organic-matter-rich soil. Soil Sci. Soc. Am. J. 2010, 74, 130-138. [CrossRef]

42. Zhang, B.; Pang, C.; Qin, J.; Liu, K.; Xu, H.; Li, H. Rice straw incorporation in winter with fertilizer-N application improves soil fertility and reduces global warming potential from a double rice paddy field. Biol. Fert. Soils 2013, 49, 1039-1052. [CrossRef]

43. Wassmann, R.; Neue, H.U.; Bueno, C.; Lantin, R.S.; Alberto, M.C.R.; Buendia, L.V.; Bronson, K.; Papen, H.; Rennenberg, H. Methane production capacities of different rice soil derived from inherent and exogenous substrates. Plant and Soil 1998, 203, 227-237. [CrossRef]

44. Lou, Y.; Xu, M.; Wang, W.; Sun, X.; Liang, C. Soil organic carbon fractions and management index after $20 \mathrm{yr}$ of manure and fertilizer application for greenhouse vegetables. Soil Use Manag. 2011, 27, 163-169. [CrossRef]

45. Wang, W.; Sardans, J.; Zeng, C.; Zhong, C.; Li, Y.; Peñuelas, J. Response of soil nutrient concentrations and stoichiometry to increased human disturbance in a subtropical tidal wetland. Geoderma 2014, 232, 459-470. [CrossRef] [PubMed]

46. Lu, R.K. Analysis Methods of Soil Science and Agricultural Chemistry; Agriculture Science and Technology Press: Beijing, China, 1999.

47. Wang, W.; Wang, C.; Sardans, J.; Min, Q.; Zeng, C.; Tong, C.; Peñuelas, J. Agricultural land use decouples soil nutrient cycles in a subtropical riparian wetland in China. Catena 2015, 133, 171-178. [CrossRef]

48. Ali, M.A.; Hoque, M.A.; Kim, P.J. Mitigating global warming potentials of methane and nitrous oxide gases from rice paddies under different irrigation regimes. Ambio 2013, 42, 357-368. [CrossRef] [PubMed]

49. Steinbeiss, S.; Gleixner, G.; Antonietti, M. Effect of biochar amendment on soil carbon balance and soil microbial activity. Soil Biol. Biochem. 2009, 41, 1301-1310. [CrossRef]

50. Spokas, K.A.; Baker, J.M.; Reicosky, D.C. Ethylene: Potential key for biochar amendment impacts. Plant Soil 2010, 333, 443-452. [CrossRef]

51. Fang, Y.; Singh, B.P.; Singh, B. Temperature sensitivity of biochar and native carbon mineralization in biochar-amended soils. Agric. Ecosyst. Environ. 2014, 191, 158-167. [CrossRef]

52. Sohi, S. Carbon storage with benefits. Science 2012, 338, 1034-1035. [CrossRef] [PubMed] 
53. Song, X.; Li, L.; Zheng, J.; Pan, G.; Zhang, X.; Zheng, J.; Hussain, Q.; Han, X.; Yu, X. Sequestration of maize crop straw $\mathrm{C}$ in different soils: Role of oxyhydrates in chemical binding and stabilization as recalcitrance. Chemosphere 2012, 87, 649-654. [CrossRef] [PubMed]

54. Cao, Z.P.; Li, D.P.; Han, X.M. The fungal to bacterial ratio in soil food webs, and its measurement. Acta Ecol. Sin. 2011, 31, 4741-4748.

55. Woolf, D.; Amonette, J.E.; Street-Perrott, F.A.; Lehmann, J.; Joseph, S. Sustainable biochar to mitigate global climate change. Nat. Commun. 2010, 1, 56. [CrossRef] [PubMed]

56. Bradford, M.A.; Davies, C.A.; Frey, S.D.; Maddox, T.R.; Melillo, J.M.; Mohan, J.E.; Reynolds, J.F.; Treseder, K.K.; Wallenstein, M.D. Thermal adaptation of soil microbial respiration to elevated temperature. Ecol. Lett. 2008, 11, 1316-1327. [CrossRef] [PubMed]

57. Bradford, M.A.; Watts, B.W.; Davies, C.A. Thermal adaptation of heterotrophic soil respiration in laboratory microcosms. Glob. Chang. Biol. 2010, 16, 1576-1588. [CrossRef]

58. Singla, A.; Inubushi, K. Effect of slag-type fertilizers on $\mathrm{N}_{2} \mathrm{O}$ flux from komatsuna vegetated soil and $\mathrm{CH}_{4}$ flux from paddy vegetated soil. Paddy Water Environ. 2015, 13, 43-50. [CrossRef]

59. Pitcher, M.C.; Cummings, J.H. Hydrogen sulphide: A bacterial toxin in ulcerative colitis? Gut 1996, 39, 1-4. [CrossRef] [PubMed]

60. O'Flaherty, V.; Mahony, T.; O'Kennedy, R.; Colleran, E. Effect of pH on growth kinetics and sulphide toxicity thresholds of a range of methaneogenic, syntrophic and sulphate-reducing bacteria. Process Biochem. 1998, 33, 555-569. [CrossRef]

61. Setia, R.; Marschner, P.; Baldock, J.; Chittleborough, D. Is $\mathrm{CO}_{2}$ evolution in saline soils affected by an osmotic effect and calcium carbonate? Biol. Fert. Soils 2010, 46, 781-792. [CrossRef]

62. Setia, R.; Marschner, P.; Baldock, J.; Chittleborough, D.; Verma, V. Relationships between carbon dioxide emission and soil properties in salt-affected landscapes. Soil Biol. Biochem. 2011, 43, 667-674. [CrossRef]

63. Chen, B.Y.; Liu, S.Q.; Huang, J.Y.; Shiau, T.J.; Wang, Y.M. Reduction of carbon dioxide emission by using microbial fuel cells during wastewater treatment. Aerosol Air Qual. Res. 2013, 13, 266-274. [CrossRef]

64. Zhu, Q.; Zeng, D.; Wang, C.; Tong, C.; Wang, W. Effects of waste applications on the distribution and stability of soil aggragates in the paddy field of Fuzhou plain. Acta Sci. Circumst. 2016, 36, 3000-3008.

(C) 2018 by the authors. Licensee MDPI, Basel, Switzerland. This article is an open access article distributed under the terms and conditions of the Creative Commons Attribution (CC BY) license (http://creativecommons.org/licenses/by/4.0/). 